\title{
Research on The Actual Condition of Youth Happiness and Related Variables
}

\author{
Hyoun-Yong Kwon1)
}

\begin{abstract}
The purpose of this study is to examine subjective happiness and student life satisfaction of children and adolescents. For this, 2,725 students from elementary school and middle school and high school in S city were surveyed. From the collected data, 2,528 data suitable for analysis were statistically processed using the SPSS 18.0 program. In order to determine the difference according to the general characteristics (Gender, school level) of the adolescents, the average value was verified. Cronbach's alpha coefficient was calculated to test the reliability of the measurement tool. The results of the analysis are as follows. First, there was a statistically significant difference in the subjective happiness of children and adolescents according to general characteristics (Gender, school grade). In comparison, male students and elementary students showed higher subjective happiness. Second, there were statistically significant differences in the student life satisfaction of children and adolescents according to general characteristics (Gender, school grade). By gender, male students were high in school life satisfaction, environmental life satisfaction, and self-satisfaction, and female students were high in friend life satisfaction. Overall, elementary school students had a high level of student life satisfaction at the school grade. This study is meaningful in that it examined the actual condition of subjective happiness of children and adolescents and school life satisfaction.
\end{abstract}

Keywords : Children, Adolescent, Subjective Happiness, Student, Life Satisfaction

\section{Introduction}

Adolescence is a period of many physical and psychological changes. In adolescence, it is time to make various attempts to break away from the dependency relationship with the parents and to become independent. However, many adolescents live by suppressing their desires with academic achievement as their primary goal. This is exposed to a less educated environment in which young people choose to achieve themselves and there is less opportunity for positive interaction[1]. This may lead to confusion of identity. Academic - oriented life in adolescence is

Received(May 03, 2019), Review Result(1st: May 30, 2019, 2nd: August 1, 2019), Accepted(September 10, 2019)

1) (Professor) 18330 Dept. Liberal Arts \& Education, Hyupsung Univ., 72, Choerubaek-ro, Bongdam-eup, Hwaseong-si, Gyeonggi-do, Korea

email: khyong@hanmail.net 
related to maladjustment, and also to the increasing tendency to lose humanity and dehumanization[2]. The habitual non-social and self-destructive desires of these adolescents not only lead to social maladjustment behaviors such as self-injurious behavior but also cause emotional problems such as anxiety or depression[3][4]. These depressive moods are associated with an increased frequency of self-harm and suicide among adolescents. Therefore, existing studies have been focused on issues related to school maladjustment, deviant behavior, problem behavior, psychosocial characteristics, and youth in crisis.

The happiness of Korean children and adolescents was the highest in 'education' and 'health and safety', and the 'subjective happiness' area was the lowest among the comparative countries[5]. The Korean government has been interested in promoting youth 's happiness and since 1990, it has provided national support such as various youth training and counseling by preparing the central ministry responsible for youth basic law and youth policy as national policy, The happiness index of Korean youth is still reported as the lowest. The percentage of adolescents who responded positively to the question "I am happy now" in Korea, China, and Japan's International Comparison Survey of Youth Values is $83.8 \%$ in China, 67\% in Korea, and $65.7 \%$ in Japan. Korea and Japan were relatively low. In this study, elementary school students were relatively happy, which suggests that the higher the grade, the greater the burden of study and career[6].

Recently, as domestic and foreign perceptions about the rights of youth have increased, they have become interested in the subjective quality of life of adolescents[7]. In addition, studies on happiness and quality of life are actively carried out by the increase of academic and social interest in the field of positive psychology, leading to various studies on happiness for children and adolescents. Research on how young people perceive their lives is very important in that they provide important intervention indicators for various behavior problems, counseling, and therapeutic interventions of adolescents[8]. In addition, adolescence is a time to prepare for an independent life in adulthood, and the quality of life and awareness related to happiness that they perceive are the basis for understanding later life quality of adulthood[9]. Therefore, the quality of life of adolescents is a result of life until now, and it is an index of future life that judges the present level of life, and it can be a predictive factor for positive development and healthy adaptation[10]. Adolescents' maladjustment and the value of academic centered life can lead to a phenomenon in which the self - identity of adolescents is deferred, and even after they have grown up to adults, they can not find their own life direction well.

As discussed above, there are various attempts to examine the positive aspect of children and adolescents besides the maladaptive side. Recently, studies on happiness have been 
conducted along with the activation of positive psychology research. However, the research on the actual condition of happiness of children and adolescents in Korea is still insufficient. Based on this survey, it is necessary to intervene to improve the happiness of children and adolescents. Therefore, in this study, we will examine subjective well-being and student life satisfaction according to general features of children and adolescents. The purpose of this study is to utilize this data as basic data for various educational and counseling interventions for the future enhancement of children and adolescents.

The research problems to carry out the purpose of this study are as follows.

Research Question 1. What is the difference of subjective happiness index according to general characteristics (sex, school level)?

Research Question 2. What is the difference in student life satisfaction according to general characteristics (sex, school level)?

\section{Research Method}

\subsection{Subject}

It was conducted for young people living in Suwon city. A total of 2,725 copies were collected. The data used in the analysis were excluded from the survey through the validation process, and $2,528(100 \%)$ of the valid samples were considered suitable for analysis. The sex ratio of sample was 1,312 (51.9\%) for male students and 1,216 (48.1\%) for female students. According to the school level, 616 students $(24.4 \%)$ were in elementary school, 1085 students $(42.9 \%)$ were middle school students, 728 students $(28.8 \%)$ were high school students in arts, and 95 students $(3.8 \%)$ were vocational high school students. And $4(0.1 \%)$ other students. When we look at the grade distribution of youth, $16.5 \%$ of the students were in the second grade of high school, Next, $16.1 \%$ of first-year high school students, $12.4 \%$ of middle school students in the third grade, $15.3 \%$ of middle school students in the second grade, $15.2 \%$ in the first grade of middle school, $14.1 \%$ in the sixth grade of elementary school, $10.2 \%$ in the fifth grade of elementary school, and $0.2 \%$ in none. 


\subsection{Measurement}

\subsubsection{Indices of Happiness for Children and Youth}

In order to calculate Development of the happiness index of Korean youth, National Youth Policy Institute (NYPI) conducted a study on the development of the Korean Youth Happy Competency Index in 2006. Subsequently, the sub-areas and detailed indicators of the six areas are discussed through the <Korean Youth Development Index Survey $\mid>[11][12]$. This study has developed 129 indicators in the first year in conjunction with <Busan Metropolitan City Basic Plan for Children and Youth Policy>. Through the refinement of the revised and supplementary works in 2011, we derived the happiness index calculation method based on 83 objective indicators and 39 subjective indicators. The subjective well-being of the adolescents was measured using the 12 items in the questionnaire. Each question is from 1 point to 5 points, from 'not at all' ( 1 point) to 'very agree' (5 points). If the score is 3 or more, it can be judged to be more than average.

\subsubsection{The Korean Version of the Multidimensional Student Life Satisfaction Scale (K-MSLSS)}

Multidimensional Students' life Satisfaction Scale (MSLSS; Huebner, 1994), which can assess the life satisfaction of children and adolescents in multidimensional terms, is regarded as one of the most comprehensive tools of positive psychological measures[13]. As a tool to measure the subjective perception of adolescents' satisfaction with their family, friends, school, self, and environment, The Korean version of the Multidimensional Student Life Satisfaction Scale (K-MSLSS), which was validated by Lee Jung-mi (2011), was used[14]. Twenty - six items consisted of friend factor satisfaction (8 items), family factor (6 items), school factor (4 items), environmental factor (5 items) and self - satisfaction ( 3 items). In this study, the reliability coefficient is Cronbach $a=.944$.

\subsection{Research Procedure}

To investigate the happiness of adolescents, literature data were surveyed and appropriate questionnaires were made and 30 preliminary surveys were conducted. The sampling method of this study used stratified cluster sampling. The subjects of the study were 2,725 students in 9 elementary schools, 9 middle schools, and 8 high schools in S city. The collected data were subjected to data validation and final analysis of 2,528 copies, excluding those who were 
unfaithful.

\subsection{Data Analysis}

The data collected in this study were statistically processed using the SPSS 18.0 program. First, Cronbach's was used to confirm the reliability of the scales used in the study. The independent sample t-test was used to determine whether there was a difference in subjective well-being and student life satisfaction according to sex, One-way analysis of variance (ANOVA) was conducted to determine whether there was any difference in subjective satisfaction index and student life satisfaction according to the school level. When significant differences were found, post - analysis was performed using the scheffe test for each subgroup of each variable.

\section{Results}

\subsection{Differences in Subjective Happiness Indicators according to General Characteristics (sex, school level)}

The $t$-test was conducted to examine the difference in subjective well-being according to the general characteristics (sex) perceived by children and adolescents. The results are shown in [Table 1]. Subjective Happiness indicators include "awareness of safety in residential areas", "priority consideration in establishing facilities and spaces", "awareness of living cities", "respect and trust from others", "Self-satisfaction", "Health awareness", "living conditions", "degree of family support when needed", "social support outside the family", "affirmation about the future", "effort and realization for dream", "perception of happiness in life". Looking at the overall response average, male students had higher Subjective Happiness indicators than female students.

[Table 1] Differences in Subjective Happiness Indicators According to Sex

\begin{tabular}{|c|c|c|c|c|c|c|}
\hline $\begin{array}{l}\text { Happiness Indicators for Children and } \\
\text { adolescents }\end{array}$ & Sex & $\mathrm{N}$ & Average & $\begin{array}{l}\text { Standard } \\
\text { deviation }\end{array}$ & $t$ & $p$ \\
\hline \multirow{2}{*}{$\begin{array}{l}\text { Do you think that the house I live in and the } \\
\text { surrounding area are safe? }\end{array}$} & Male & 1312 & 3.02 & .999 & 7.321 & .000 \\
\hline & Female & 1213 & 2.73 & 1.019 & & \\
\hline \multirow{2}{*}{$\begin{array}{l}\text { Do you think that } S \text { city gives priority to children and } \\
\text { adolescents when creating parks, sports facilities, } \\
\text { cultural spaces, streets, etc.? }\end{array}$} & Male & 1312 & 2.76 & 1.078 & 4.507 & .000 \\
\hline & Female & 1215 & 2.58 & .952 & & \\
\hline \multirow{2}{*}{$\begin{array}{l}\text { Do you think } S \text { city is a good city for children and } \\
\text { adolescents? }\end{array}$} & Male & 1311 & 2.86 & 1.048 & 5.150 & .000 \\
\hline & Female & 1215 & 2.65 & .972 & & \\
\hline \multirow{2}{*}{$\begin{array}{l}\text { Do you think I am respected and trusted as a } \\
\text { precious being? }\end{array}$} & Male & 1310 & 3.01 & .974 & 2.885 & .004 \\
\hline & Female & 1215 & 2.90 & .897 & & \\
\hline
\end{tabular}




\begin{tabular}{|c|c|c|c|c|c|c|}
\hline \multirow{2}{*}{$\begin{array}{l}\text { Are you satisfied with your current appearance (looks, } \\
\text { abilities, values, etc.)? }\end{array}$} & Male & 1312 & 2.90 & 1.062 & 9.240 & .000 \\
\hline & Female & 1215 & 2.50 & 1.117 & & \\
\hline \multirow{2}{*}{$\begin{array}{l}\text { Do you think that you usually have enough physical } \\
\text { strength to be healthy and active? }\end{array}$} & Male & 1311 & 2.94 & 1.049 & 7.377 & .000 \\
\hline & Female & 1216 & 2.62 & 1.081 & & \\
\hline \multirow{2}{*}{$\begin{array}{l}\text { Do you live well enough to buy or have what you } \\
\text { want and need? }\end{array}$} & Male & 1312 & 2.90 & .993 & 1.847 & .065 \\
\hline & Female & 1216 & 2.83 & .918 & & \\
\hline \multirow{2}{*}{$\begin{array}{l}\text { Do you think family members can help me when I } \\
\text { need them? }\end{array}$} & Male & 1312 & 3.24 & .896 & 1.355 & .176 \\
\hline & Female & 1216 & 3.19 & .872 & & \\
\hline \multirow{2}{*}{$\begin{array}{l}\text { Do you think there is an agency to get the help or } \\
\text { support you need for your future, except your family? }\end{array}$} & Male & 1309 & 2.77 & 1.090 & 5.451 & .000 \\
\hline & Female & 1215 & 2.54 & 1.032 & & \\
\hline \multirow{2}{*}{ Do you think my life is likely to be better than now? } & Male & 1310 & 3.11 & .968 & 3.540 & .000 \\
\hline & Female & 1216 & 2.98 & .913 & & \\
\hline \multirow{2}{*}{$\begin{array}{l}\text { Do you think you can achieve dreams (college } \\
\text { entrance, occupation, etc.) if you try hard even though } \\
\text { you have difficulties in life and hard work? }\end{array}$} & Male & 1310 & 3.06 & 1.036 & 2.086 & .037 \\
\hline & Female & 1216 & 2.97 & 1.014 & & \\
\hline \multirow{2}{*}{ Do you usually feel happy in my life? } & Male & 1312 & 3.09 & 1.006 & 5.538 & .000 \\
\hline & Female & 1216 & 2.87 & .985 & & \\
\hline
\end{tabular}

F-test was conducted to investigate the difference in student life satisfaction according to general characteristics (school level) perceived by children and adolescents, and the results are shown in [Table 2]. Subjective Happiness indicators include "awareness of safety in residential areas", "priority consideration in establishing facilities and spaces", "awareness of living cities", "respect and trust from others", "Self-satisfaction", "Health awareness", "living conditions", "degree of family support when needed", "social support outside the family", "affirmation about the future", "effort and realization for dream", "perception of happiness in life". In terms of overall responses, elementary school students had higher Subjective Happiness indicators than middle and high school students.

[Table 2] Differences in Subjective Happiness Indicators According to School Level

\begin{tabular}{|c|c|c|c|c|c|c|}
\hline $\begin{array}{c}\text { Happiness Indicators for Children and } \\
\text { adolescents }\end{array}$ & school level & $\mathrm{N}$ & Average & $\begin{array}{l}\text { Standard } \\
\text { deviation }\end{array}$ & $F$ & scheffe \\
\hline \multirow{4}{*}{$\begin{array}{l}\text { Do you think that the house I live in and } \\
\text { the surrounding area are safe? }\end{array}$} & Elementary School & 613 & 3.13 & .996 & \multirow{4}{*}{$45.451^{* \star *}$} & \multirow{4}{*}{$a>b>c$} \\
\hline & middle School & 1085 & 2.92 & .994 & & \\
\hline & high school & 827 & 2.63 & 1.017 & & \\
\hline & Total & 2525 & 2.88 & 1.019 & & \\
\hline \multirow{4}{*}{$\begin{array}{l}\text { Do you think that } S \text { city gives priority to } \\
\text { children and adolescents when creating } \\
\text { parks, sports facilities, cultural spaces, } \\
\text { streets, etc.? }\end{array}$} & Elementary School & 615 & 2.86 & 1.036 & \multirow{4}{*}{$35.472^{\star \star *}$} & \multirow{4}{*}{$a, b>c$} \\
\hline & middle School & 1085 & 2.74 & .996 & & \\
\hline & high school & 827 & 2.44 & 1.007 & & \\
\hline & Total & 2527 & 2.67 & 1.023 & & \\
\hline \multirow{4}{*}{$\begin{array}{l}\text { Do you think } S \text { city is a good city for } \\
\text { children and adolescents? }\end{array}$} & Elementary School & 614 & 3.08 & .969 & \multirow{4}{*}{$76.825^{* * *}$} & \multirow{4}{*}{$a>b>c$} \\
\hline & middle School & 1085 & 2.82 & .976 & & \\
\hline & high school & 827 & 2.44 & 1.018 & & \\
\hline & Total & 2526 & 2.76 & 1.017 & & \\
\hline Do you think I am respected and trusted & Elementary School & 615 & 3.15 & .931 & $25.284^{* \star *}$ & $\mathrm{a}>\mathrm{b}>\mathrm{c}$ \\
\hline
\end{tabular}


Asia-pacific Journal of Convergent Research Interchange

Vol.5, No.3, September 30 (2019), pp. 179-188

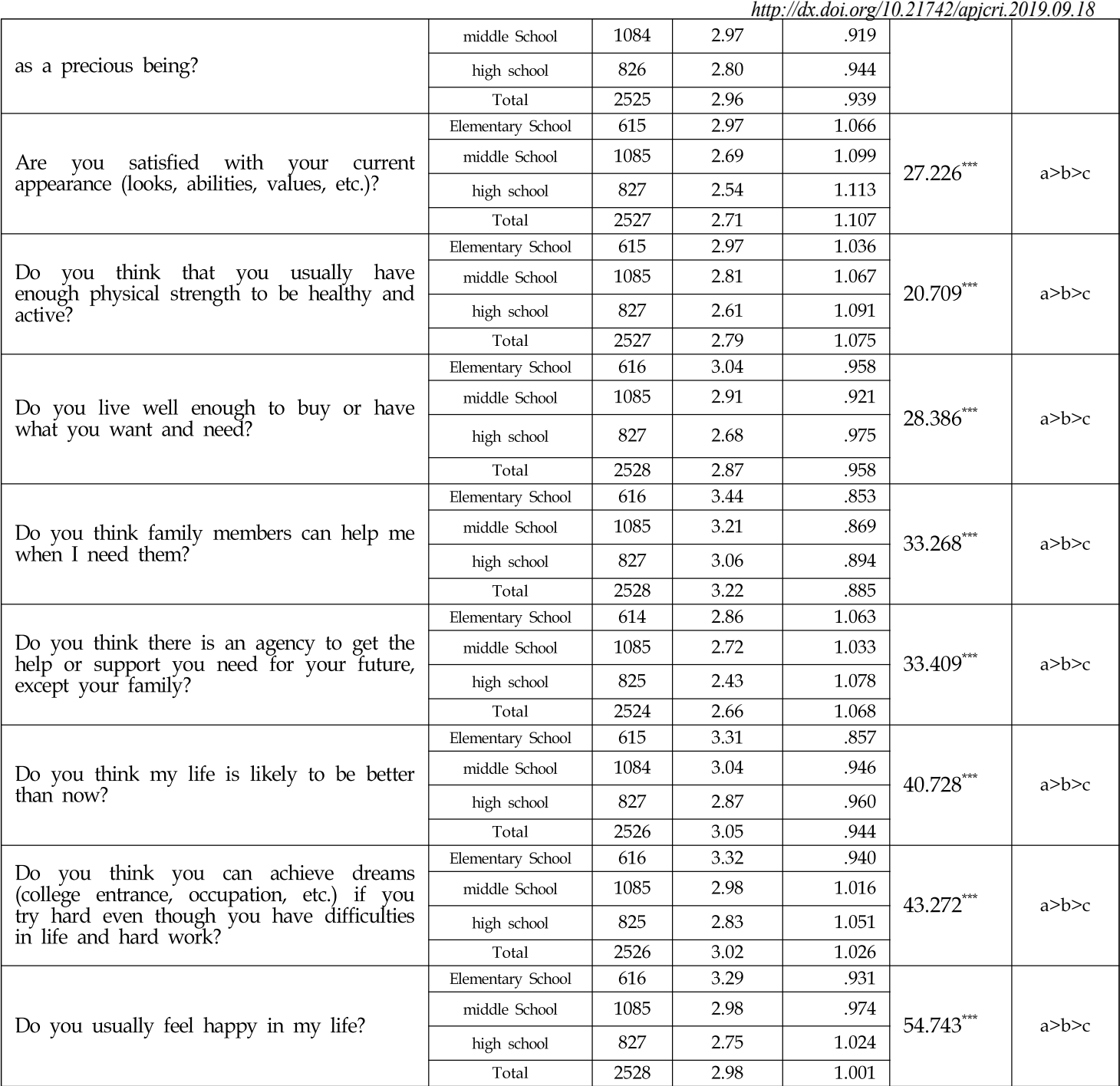

$p<.001, \mathrm{a}=$ =lementary School, $\mathrm{b}=$ middle School, $\mathrm{c}=$ high school

\subsection{Differences in Student Life Satisfaction according to General Characteristics (sex, school level)}

The $t$-test was conducted to investigate the difference in student life satisfaction according to the general characteristics (sex) perceived by children and adolescents, and the results are shown in [Table 3]. Among the sub-factors of student life satisfaction, the average of school life satisfaction, environmental life satisfaction, male students had higher student life satisfaction than female students. However, in friend life satisfaction, the female students were higher than male students. 
Research on the Actual Condition of Youth Happiness and Related Variables

[Table 3] Differences in Student Life Satisfaction According to Sex

\begin{tabular}{|l|l|c|c|c|c|c|}
\hline \multicolumn{1}{|c|}{ Student Life Satisfaction } & \multicolumn{1}{c|}{ Sex } & $\mathrm{N}$ & Average & $\begin{array}{c}\text { Standard } \\
\text { deviation }\end{array}$ & $t$ & $p$ \\
\hline \multirow{2}{*}{ family life satisfaction } & Male & 1310 & 18.15 & 5.151 & .990 & .322 \\
\cline { 2 - 7 } & Female & 1213 & 17.95 & 5.051 & & \\
\hline \multirow{2}{*}{ friend life satisfaction } & Male & 1310 & 24.24 & 5.302 & -2.631 & .009 \\
\cline { 2 - 7 } & Female & 1210 & 24.79 & 5.341 & & \\
\hline \multirow{2}{*}{ school life satisfaction } & Male & 1311 & 10.16 & 4.253 & 2.893 & .004 \\
\cline { 2 - 7 } & Female & 1213 & 9.67 & 4.187 & & \\
\hline \multirow{2}{*}{ environmental life satisfaction } & Male & 1310 & 14.49 & 3.888 & 4.095 & .000 \\
\cline { 2 - 7 } & Female & 1213 & 13.85 & 3.925 & & \\
\hline \multirow{2}{*}{ self-satisfaction } & Male & 1310 & 9.09 & 2.653 & 5.761 & .000 \\
\cline { 2 - 7 } & Female & 1213 & 8.48 & 2.649 & & \\
\hline
\end{tabular}

F-test was conducted to investigate the difference in student life satisfaction according to general characteristics (school level) perceived by children and adolescents. The results are shown in [Table 4]. Among the sub-factors of student life satisfaction, the average of family life satisfaction, friend life satisfaction, school life satisfaction, environmental life satisfaction and self satisfaction, elementary school students had higher overall student life satisfaction than middle and high school students.

[Table 4] Differences in Student Life Satisfaction According to School Level

\begin{tabular}{|c|c|c|c|c|c|c|}
\hline Student Life Satisfaction & School level & $\mathrm{N}$ & Average & $\begin{array}{l}\text { Standard } \\
\text { deviation }\end{array}$ & $\mathrm{F}$ & Scheffe \\
\hline \multirow{4}{*}{ family life satisfaction } & Elementary School & 614 & 19.25 & 4.936 & \multirow{4}{*}{$27.620 * * *$} & \multirow{4}{*}{$a>b>c$} \\
\hline & middle School & 1084 & 17.98 & 5.150 & & \\
\hline & high school & 825 & 17.26 & 5.002 & & \\
\hline & Total & 2523 & 18.06 & 5.103 & & \\
\hline \multirow{4}{*}{ friend life satisfaction } & Elementary School & 615 & 25.72 & 5.482 & \multirow{4}{*}{$27.849^{* * *}$} & \multirow{4}{*}{$\mathrm{a}>\mathrm{b}>\mathrm{c}$} \\
\hline & middle School & 1082 & 24.48 & 5.164 & & \\
\hline & high school & 823 & 23.63 & 5.251 & & \\
\hline & Total & 2520 & 24.50 & 5.327 & & \\
\hline \multirow{4}{*}{ school life satisfaction } & Elementary School & 615 & 10.68 & 4.233 & \multirow{4}{*}{$14.478^{* * *}$} & \multirow{4}{*}{$a>b, c$} \\
\hline & middle School & 1084 & 9.82 & 4.199 & & \\
\hline & high school & 825 & 9.50 & 4.193 & & \\
\hline & Total & 2524 & 9.92 & 4.228 & & \\
\hline \multirow{4}{*}{ environmental life satisfaction } & Elementary School & 615 & 15.31 & 4.168 & \multirow{4}{*}{$47.158^{* * *}$} & \multirow{4}{*}{$\mathrm{a}>\mathrm{b}>\mathrm{c}$} \\
\hline & middle School & 1083 & 14.21 & 3.793 & & \\
\hline & high school & 825 & 13.32 & 3.667 & & \\
\hline & Total & 2523 & 14.19 & 3.918 & & \\
\hline \multirow{4}{*}{ self-satisfaction } & Elementary School & 615 & 9.37 & 2.504 & \multirow{4}{*}{$21.635^{* * *}$} & \multirow{4}{*}{$a>b, c$} \\
\hline & middle School & 1082 & 8.74 & 2.688 & & \\
\hline & high school & 826 & 8.45 & 2.694 & & \\
\hline & Total & 2523 & 8.80 & 2.668 & & \\
\hline
\end{tabular}




\section{Discussion and Conclusion}

The purpose of this study was to investigate the difference of subjective happiness and student life satisfaction according to general characteristics (sex, school level) of children and adolescents. The results obtained from this study are summarized and discussed as follows. In Study Question 1, there were statistically significant differences in subjective happiness of children and adolescents according to general characteristics (sex, school level). In comparison, male students and elementary students showed higher subjective happiness. The relatively high happiness of elementary school students was the same as in the comparative study of Korea, China and Japan[6]. This is because elementary school students are relatively less burdened with academic and career paths. In Study Question 2, there were statistically significant differences in the student life satisfaction of children and adolescents according to general characteristics (sex, school level). By sex, male students were high in school life satisfaction, environmental life satisfaction, and self-satisfaction, and female students were high in friend life satisfaction. Overall, elementary school students had a high level of student life satisfaction at the school level. In the upper grades of elementary school, self-esteem, life satisfaction, and peer attachment significantly influenced school life adaptation[15].

Based on the results of this study, it is expected that the development of programs for various happiness enhancement will be carried out in the follow - up study with the increased interest of children and adolescents. Especially, in the case of female students, subjective satisfaction index and student life satisfaction were relatively low. Therefore, an in-depth harvest study of female students' happiness is needed.

\section{References}

[1] G. B. Lee, Happiness and Educational Culture in Korea, Studies on Korean Youth, (2009), Vol.20, No.1, pp.365-392, UCI: G704-001385.2009.20.1.004

[2] G. S. Kim and H. W. Nam, A test of short-term predictors of desistance from delinquent behaviors in middle adolescents, Studies on Korean Youth, (2012), Vol.23, No.4, pp.131-157, UCI: G704-001385.2012.23.4.004

[3] S. M. Park, An Analysis of the Problems Experienced by Adolescents based on the Non-humanity Type of Adolescent, Studies on Korean Youth, (2010), Vol.21, No.4, pp.201-227, UCI: G704-001385.2010.21.4.009

[4] H. Sumnall, M. A. Belisi, K. Hughes, A. Calafat, M. Juan, F. Mendes, A choice between fun or health? 
Relationships between nightlife substance use, happiness, and mental well-being, Journal of Substance Use, (2010), Vol.15, No.2, pp.89-104, DOI: https://doi.org/10.3109/14659890903131190

[5] J. I. Park, C. U. Park, H. J. Seo and Y. S. Youm, Collection of Korean Child Well-Being Index and Its International Comparison with other OECD Countries, Korean Journal of Sociology, (2010), Vol.44, No.2, pp.121-154, UCI: G704-000205.2010.44.2.005

[6] 2012 International Survey on Youth's Values, Ministry of Gender Equality and Family, (2012)

[7] H. W. Hwang, A Research on Protective Factors Influencing on Adolescents' Quality of Life, Korean Journal of Youth Studies, (2011), Vol.18, No.3. pp.1-26, UCI: G704-000387.2011.18.3.007

[8] T. C. Edwards, C. E. Huebner, F. A. Connell, D. L. Patrick, Adolescent quality of life, part I: Conceptual and measurement model, Journal of Adolescence, (2002), Vol.25, No.3, pp.275-286, DOI: 10.1006/jado.2002.0470

[9] Y. H. Jung, The factors related to the quality of adolescents in a former mining town, Kang-Won University, Master's Thesis, (2007)

[10] M. A. Nam, Factors Influencing to the Quality of Life of the Juvenile Delinquents in the Juvenile Justice Process, Korean Journal of Social Welfare, (2006), Vol.58, No.1, pp.265-290, UCI: G704-000330.2006.58.1.013

[11] Korea Youth Development Index Survey I : A comprehensive index of youth development, National Youth Policy Institute, (2006)

[12] Development of Korean Youth Happiness and Competency Index, National Youth Policy Institute, (2006)

[13] E. S. Huebner, Preliminary development and validation of a multidimensional life satisfaction scale for children, Psychological Assessment, (1994), Vol.6, No.2, pp.149-158, DOI: https://doi.org/10.1037/1040-3590.6.2.149

[14] J. M. Lee, Validation of the Korean Version of Multidimensional Students' Life Satisfaction Scale(K-MSLSS) for Adolescents, The Korean Journal of Developmental Psychology, (2011), Vol.24, No.4, pp.115-133, UCI: G704-000281.2011.24.4.001

[15] S. H. Cho, \& H. S. Kim, The influence of Self-esteem of Higher Grade Elementary School on School Life Adaptation : Focusing on the mediating effects of Peer Attachment, The Journal of Learner-Centered Curriculum and Instruction, (2016), Vol.16, No.5, pp.355-376, UCI: G704-001586.2016.16.5.018 